\title{
The Understanding of Universitas Negeri Surabaya Students of Sexual Violence on Campus
}

\author{
Elisabeth Septin Puspoayu ${ }^{1, *}$ Dian Ayu Larasati ${ }^{2}$, Iman Pasu Marganda H. P. ${ }^{3}$, Graciela \\ Natasha Tessalonica Lektonpessy ${ }^{4}$, Laily Wahyuningtyas Putri Hariono ${ }^{5}$ \\ 1,2, 3, 4, 5 Universitas Negeri Surabaya
}

*Corresponding author. Email: elisabethpuspoayu@unesa.ac.id

\begin{abstract}
A violence that happens against women has become an interesting discussion. Indonesia has been in an emergency situation at protection from sexual violence mainly for women. Law No. 23 of 2004 on Elimination of Domestic Violence, Law No. 23 of 2002 which has amended by Law No. 35 of 2014 on Amending Law on Child Protection, Law No. 21 of 2007 on the crime of trafficking in person recognize other types of violence, however, those three laws have limited scope for classifying the type of sexual violence and the protection towards the victim and the family that affected by sexual violence. Sexual violence not only takes place in the family environments but in schools as well, mainly on campus, the student's understanding about the types of sexual violence needs sharpening to enlighten them so they can prevent the sexual violence on campus. This research aims to know how the Universitas Negeri Surabaya student knowledge about the types of sexual violence on campus and to describe the Universitas Negeri Surabaya student understanding in sexual violence on campus.
\end{abstract}

Keywords-PUNGKAS Bill; Sexual Violence; Human Rights

\section{INTRODUCTION}

Violence against women has become an increasingly interesting discussion topic. What makes Indonesia experience an emergency is the protection of sexual violence, especially for women. This has prompted many parties to demand that the DPR RI include the Draft Law on the Protection of Victims of Sexual Violence in the National Legislation Program or Prolegnas. The House of Representatives of the Republic of Indonesia quickly respond to and include the Draft Law on the Elimination of Sexual Violence (RUU-PKS) into the priority National Legislation Program. This is a form of refinement of the law that regulates sexual violence. The Criminal Code (KUHP) only regulates the crime of rape as regulated in articles 285 to 288 whose formulation does not provide protection for victims of violence. In context rape, the interpretation of Indonesian law also only accommodates acts of forced sexual intercourse as penetration of the penis into the vagina with evidence of physical violence due to the penetration (visum).

Law No. 23 of 2004 on the Elimination of Domestic Violence, Law No. 23 of 2002 which was amended in Law no. 35 of 2014 concerning Child Protection, Law no. 21 of 2007 concerning the Eradication of the Crime of Trafficking in
Persons recognizes other forms of violence, but the three laws have a limited scope regarding the classification and types of sexual crimes as well as the protection of victims and their familiof es affected by sexual violence. Meanwhile, in the international concept of protection for women, it has been stated in the declaration of human rights, International Covenant on Civil and Political Rights (ICCPR), Convention on the Elimination of all Forms of Discrimination Against Woman (CEDAW). This international rule regulates how the international community supports the fulfillment of human rights in a complete and inviolable way for both men and women. In 2014, the National Commission on Violence Against Women (Komnas Perempuan) and the Service Provider Forum took the initiative to formulate an Academic Paper on the Draft Law on the Elimination of Sexual Violence (RUU PKS).

The formulation of the PKS Bill was motivated by the increasing prevalence of sexual violence. Based on Komnas Perempuan's 2018 Annual Records (CATAHU), the number of sexual violence cases reported in 2017 increased by $74 \%$ from 2016(NN, 2018). Like the iceberg phenomenon, the numbers and percentages recorded in this report do not yet show the total number of cases that exist. With the PKS Bill, victims of sexual 
violence can get protection from the state, including recovery from the violence they experienced. This is a fulfillment of state obligations and as a guarantee that the community is free from all forms of sexual violence.

In 2017, The data from National Commission on Violence Against Women showed the amount of the reported cases increased to $74 \%$ then from 2016. There were 348.446 cases in 2017 and 259.150 cases in 2016. Based on those collected data, in the kinds of violence against women, domestic violence (personal affair) still become the prominent case as like years before which reached $71 \%$ (9.609). Personal affair is the most reported cases and many of them experienced the sexual violation. The second is community/public concern with $26 \%$ (3.528) and the last is state sphere with 1,8\% (217). In domestic violence/personal affairs, physical violence is the most conspicuous with 3.982 cases $(41 \%)$, as the first place followed by sexual violence with 2.979 cases $(31 \%)$, psychological 1.404 (15\%) and economic with 1.244 cases (13\%). In public and community concern, there were 3,528 recorded cases. The $76 \%$ of violence against women in public or community concern is sexual assault as one type of sexual violence with 911 cases, sexual harassment (704) and rape (699), sexual coercion with 343 cases (komnas perempuan, 2020)

Domestic violence/personal affair, intimate partner violence against women is having in the first place with 5.167 cases $(54 \%)$, followed by violence against boyfriend/girlfriend during the relationship with 1.873 cases $(19 \%)$, violence against girl child with 2.227 cases $(23 \%)$ and the rest is violence from a former husband or ex-boyfriend, and also violence against domestic workers. The high number of violence against girl child, many of them were experiencing sexual violence. Even one of the worrying aspects is incest cases with 1.210 cases, while the perpetrator is their biological father with 425 cases. The concern and courage to report cases of violence against themselves to service institutions show as a step forward of women that they tend to cover it up and cultivate the impunity of family perpetrators this whole time.

Women protection as part of Indonesian citizen is States' obligation. A statutory law to protect women is not enough due to some campus circumstances as the location that sexual violence often happens. The students of Universitas Negeri Surabaya as the agent of change need the knowledge and understanding about sexual violence against women on campus to protect and prevent sexual violence on campus.

\section{METHODS}

This research is qualitative research. A qualitative research method is a research method used to examine the condition of natural objects (as opposed to experiments) where the researcher is the key instrument, source, and data collection is carried out purposively and snowball, data collection techniques are carried out by triangulation (combined). inductive/qualitative, and qualitative research results emphasize more on meaning than generalization (Sugiono, 2003). This research methodologically identifies primary data on community conditions related to sexual violence, especially the understanding of Univrsitas Negeri Surabaya students regarding the existence of sexual violence that also occurs in the campus environment. And secondary data is obtained from ready-made form data that has been collected and obtained by other parties, usually in the form of publications.

\section{RESUTS AND DISCUSSION}

Hereby, the data as proof that the Universitas Negeri Surabaya's students as the agent of change has the knowledge and understanding about sexual violence against women on campus to protect and prevent the sexual violence on campus. There are some choises that stand for something, i.e SS for "Sangat Setuju" means strongly agree, S for "Setuju" means agree, TS for "Tidak Setuju" means dissagree, and STS for "Sangat Tidak Setuju" means strongly dissagree. This research has collected 500 Universitas Negeri Surabaya's students from different faculties with $81,8 \%$ of them are women, and the rest at $18,2 \%$ are men. The data are came by some statements which has delivered to the students about the kinds of sexual harassment of sexual violence which are included as sexual behavior which is delivered through physical or non-physical contact that targets a person's sexual body parts or sexuality including by using whistles, flirting, comments of sexual nuance, showing pornographic materials and sexual desires, pokes or touches on body parts, gestures or gestures sexual intercourse, causing discomfort, being offended and feeling humiliated and can cause health and safety problems (Anindyajati, 2013) and also intimidation, threat, and rape attempt that has to be delivered directly or through via online e.g sms, email, letter, WA, DM, and any others (Anindyajati, 2013).

\section{DIAGRAM I. PROCENTAGE OF RESPONDENTS INTEPRATE WHETHER LOOK AT THE PART OF GIRL/BOY FRIEND BODY IN THE CLASS IS NORMAL}

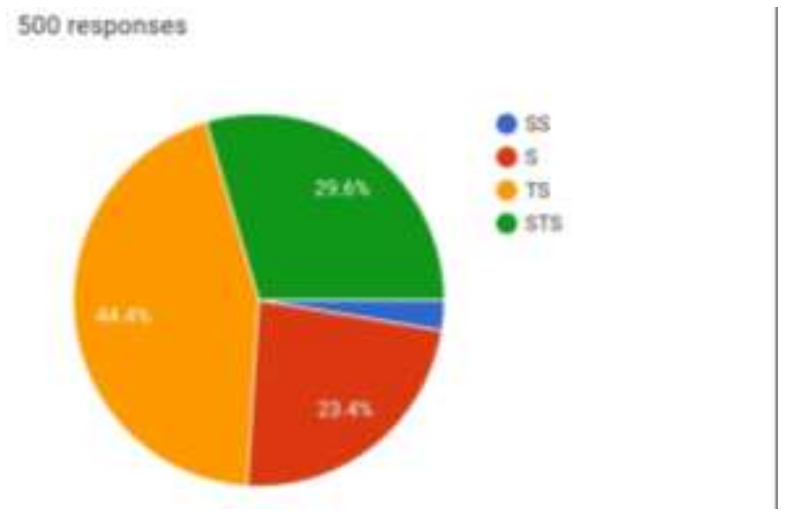

This first statement is whether look at the part of girl/boy friends body in the class is normal. There are $29,6 \%$ (148) of the respondents are strongly dissagreed and there are $44,4 \%$ (222) respondents dissagree. While 23,4\% (117) agree and the rest of 2,6\% (13) decide to strongly agree with the statement.

Then, the next is more specific to know how they respond on whether give a sensual gaze to the women or men genetical spot is normal 
DIAGRAM II. PROCENTAGE OF RESPONDENTS INTEPRATE WHETHER GIVE A SENSUAL GAZE TO THE WOMEN OR MEN GENETICAL SPOT IS NORMAL

\section{0 responses}

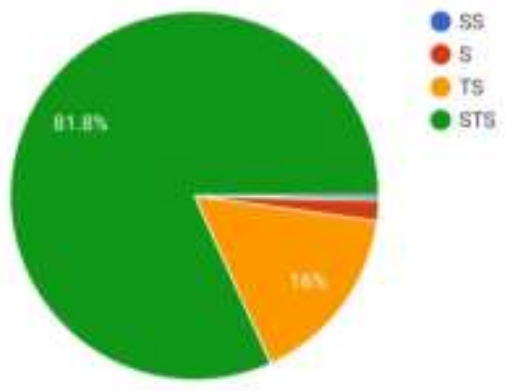

The result of this statement shows that $81,8 \%$ (409) respondents strongly dissagree, $16 \%$ (80) are dissagree, also $1.8 \%$ (9) respondents are agree, $0.4 \%$ (2) strongly agree.

The next statement is about the student respond whether give a comment on physical appearance (women or men) is normal

DIAGRAM III. PROCENTAGE OF RESPONDENTS INTEPRATE WHETHER GIVE A COMMENT ON PHYSICAL APPEARANCE (WOMEN OR MEN) IS NORMAL 500 responses

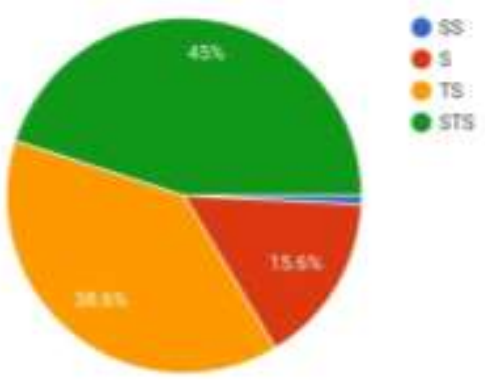

The result shows that there are 45\% (225) respondents are strongly dissagree, $36,6 \%$ (193) respondents are dissagree, and there are $15,6 \%$ (78) respondents are agree, and the rest of $0,8 \%$ (4) are strongly agree.

Related with the last statement, the next statements is whether make fun of particular part of the opposite gender body is normal.

DIAGRAM IV. PROCENTAGE OF RESPONDENTS INTEPRATE WHETHER MAKE FUN OF PARTICULAR PART OF THE OPPOSITE GENDER BODY IS NORMAL

\section{0 responses}

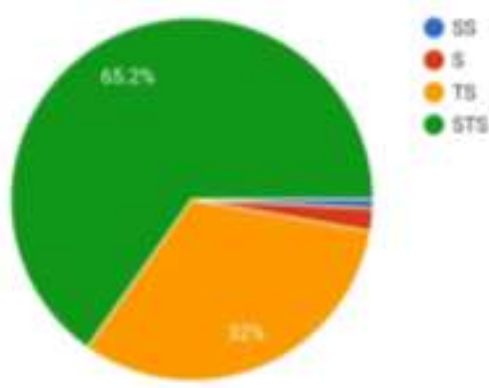

This statement shows that $65,2 \%$ (326) are strongly dissagree, and $32 \%$ (160) chose to dissagree, but it reveals better answer than the previous statement. But, there are $2 \%$ (10) respondents agree and $0,8 \%$ (4) are strongly agree if someone makes fun of the particular part of opposite gender body

This fourth statement is related with cat calling from someone. There are many kinds of it, based on talk to, call up, or greet but it is using sensual tone towards someone that make that one uncomfertable. The statement is whether to talk/call/greet someone with sensual tone (cat calling) to the others people is normal.

\section{DIAGRAM V. PROCENTAGE OF RESPONDENTS INTEPRATE WHETHER GIVING CATCALLING IS NORMAL}

500 responses

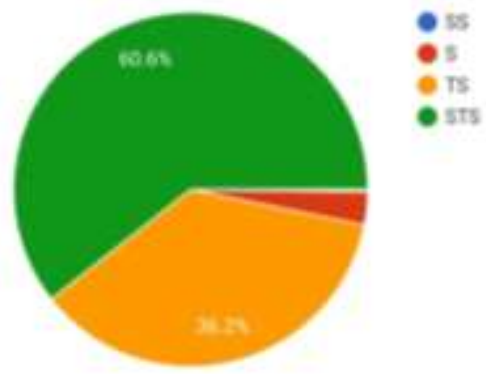

The results obtained are $60.6 \%$ (303) of respondents strongly dissagree and $36.2 \%$ (181) answered dissagree, this shows that many students think this behavior is not fair. There are also $3 \%$ (15) respondenswered agree and think this is a natural thing, $0.2 \%$ (1) strongly agree

Furthermore, we provide a statement that it is normal to send verbal messages, written, images that contain sexual content

DIAGRAM VI. PROCENTAGE OF RESPONDENTS INTEPRATE WHETHER SENDING MESSAGES, EITHER VERBAL, WRITTEN, OR IMAGES THAT CONTAIN SEXUAL CONTENT IS NORMAL

500 responses

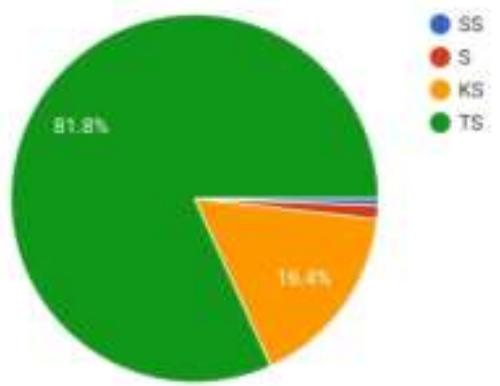


From the results obtained, as many as $81.8 \%$ (409) of respondents answered that they strongly dissagreed if this was considered reasonable, also $16.4 \%$ (82) answered that they did not agree. Meanwhile, 1.2\%(6) of respondents stated that they agreed with this behavior and $0.6 \%$ (3) answered that they strongly agreed with sending sexually charged messages.

Still related to sending messages, in the next statement we provide a statement that it is normal to send verbal messages, texts, or images that threaten each other.

DIAGRAM VII. PROCENTAGE OF RESPONDENTS INTEPRATE WHETHER
SENDING MESSAGES EITHER VERBAL, WRITTEN, OR IMAGES THAT THREATEN EACH OTHER

500 responses

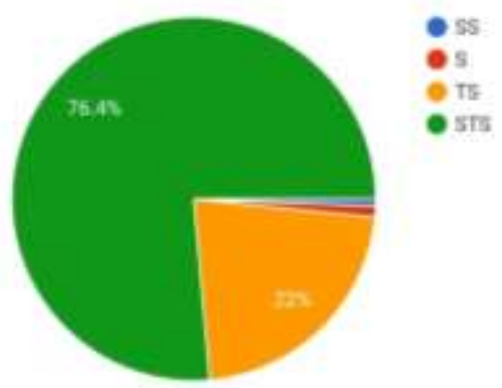

From the responses obtained there were $76.4 \%$ (382) answered that they strongly dissagreed and there were $22 \%$ (110) who answered that they did not agree, while for those who agreed there were $1 \%(5)$ respondents and those who strongly agreed were $0,6 \%(3)$ respondents.

The last statement is their response to the statement that having sexual relations outside of marriage is normal

DIAGRAM VIII. PROCENTAGE OF RESPONDENTS INTEPRATE WHETHER HAVING SEX OUSIDE OF MARRIAGE IS NORMAL

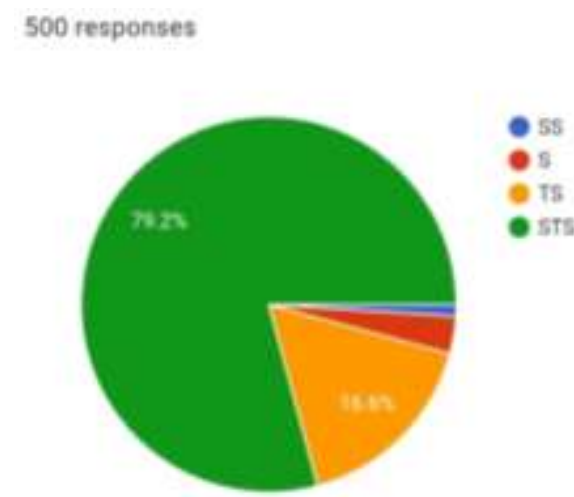

The result is $79.2 \%$ (396) stated that they strongly dissagree with this statement, $16.6 \%(83)$ dissagree, 3.2\%(16) agree, and $1 \%(5)$ strongly agree.

From the data that has been presented, it can be seen that most of the students of Universitas Negeri Surabaya are familiar ith the knowledge about the forms of sexual violence and answered that they do not agree with the various types of sexual violence, but some students do not understand the meaning of sexual violence that often occurred therefore because of these, there are some students answered that they agreed or strongly agreed with several examples of sexual violence proposed from these statements.

\section{CONSLUSION}

Sexual violence refers more to derivative sexual behavior or deviant relationships that harm the victim and can cause prolonged trauma to the victim. The public view that generally views sexual violence as only a violation of decency triggers the view that this is a matter of morality alone, where the pople always mark their sanctity and morality on women. Komnas Perempuan as the national comission that works on women's issues in Indonesia, has categorized the types of sexual violence based on years of assesment and has resulted 14 types of sexual violence which fully possible to be found in Indonesia.

One of those types is sexual violence on school, mainly on campus, neither Universitas Negeri Surabaya. The data shows how the Universitas Negeri Surabaya's students have the knowledge and understanding about sexual violence so they can decide to dissgree or fully dissagree. But also, some of them still strugling to decide whether they agree or fully agree. The result show that most of the students have the knowledge to determine types of sexual violence even there are few students cannot fully understand the types of sexual violence on campus. Therefore, the knowledge about sexual violence must be spread widely and rapidly to built their awareness on sexual violence that happen frequently and educate the students to do some acts for diminishing sexual violence on campus.

\section{REFERENCES}

[1] Anindyajati, G, Kekerasan Seksual. Modul Pelatihan Layanan Kesehatan Seksual Dan Reproduksi Ramah Remaja Untuk Dokter Praktik Swasta Di Daerah Istimewa Yogyakarta (Kemitraan UNFPA Dan Angsamerah Institusi. 2013.

[2] Komnas Perempuan, "In perempuan dalam himpitan pandemi: lonjakan kekerasan seksual, kekerasan siber, perkawinan anak, keterbatasan penanganan di tengah pandemi," Catahu Komnas Peremp. 2021, vol. 1, no. 1, 2020.

[3] NN, "Komisi nasional anti kekerasan terhadap perempuan, 2018,"

2018. https://www.komnasperempuan.go.id/file/pdf_file/2018/P ublikasi/Catatan.

[4] R. Soesilo, Kitab Undang-Undang Hukum Pidana (KUHP). Politeia, 1996. 